\title{
Are Rational Self-Interested Leadership Behaviors Contributing to the Workplace Bullying Phenomenon in Canada and the United States?
}

\author{
Lisa M. S. Barrow ${ }^{1 *}$, Sandy Kolberg ${ }^{2}$, Jim Mirabella ${ }^{3}$, Annette Roter ${ }^{4}$ \\ ${ }^{1}$ Goodman School of Business, Brock University, St. Catharines, Canada; ${ }^{2}$ School of Management, Walden University, Minneapolis, \\ USA; ${ }^{3}$ Operations Management \& Statistics, Jacksonville University, Jacksonville, USA; ${ }^{4}$ Dahl School of Business, Viterbo Univer- \\ sity, La Crosse, USA. \\ Email: *lbarrow@brocku.ca, sandra.kolberg@waldenu.edu, jmirabe@ju.edu, abroter@viterbo.edu
}

Received September $10^{\text {th }}, 2013$; revised September $28^{\text {th }}, 2013$; accepted October $3^{\text {rd }}, 2013$

Copyright (c) 2013 Lisa M. S. Barrow et al. This is an open access article distributed under the Creative Commons Attribution License, which permits unrestricted use, distribution, and reproduction in any medium, provided the original work is properly cited.

\begin{abstract}
Workplace bullying is a phenomenon in American and Canadian organizations that has been ignored for many years and as a result targeted employees are suffering [1-3]. Workplace bullying is at epidemic proportions with little done to address the issue. The workplace for bullied employees has become an uncivilized and hostile environment [4]. Leaders who embrace a rational self-interested approach to leading are contributing to the workplace bullying phenomenon. Using Chi Square tests of independence, the study was conducted to determine the extent to which rational self-interested leaders rely on bullying behaviors when interacting with employees. Three hundred fifty-five employees were asked to complete a survey consisting of fifteen bullying behavior statements. The results of the Chi Square tests indicate a significant relationship exists between employee demographics vs. certain bullying behaviors associated with threats to personal standing, professional status and destabilization. The results further reveal that rational self-interested leaders are relying on bullying in three areas: threat to personal standing, threat to professional status and destabilization. It was also noted that if the rational self-interest leader did not make changes the problem of workplace bullying would continue to escalate. The recommendation was that rational self-interested leaders could benefit by changing their perspective on employees to include more personal and humane treatment, rewards, and recognition.
\end{abstract}

Keywords: Leadership; Bullying; Leaders; Workplace Bullying; Leadership Behaviors

\section{Introduction}

Workplace bullying is a prevalent phenomenon in American and Canadian workplaces. It is the systemic persecution of employees [4]. Workplace bullying is a counterproductive behavior [5]. An estimated 37 percent of employees were subjected to ongoing bullying behavior [6]. With bullying at an epidemic level, the time has come for organizational leaders to take the necessary steps to address the issue.

Leaders can begin to address workplace bullying by examining their personal interactions with employees to determine if their attitudes and behavior are contributing to the problem. The leaders can further explore their adopted leadership approaches to determine if they are helping to promote bullying behaviors in the workplace. A review of the literature revealed leaders who embrace

\footnotetext{
*Corresponding author.
}

rational self-interest leadership approaches appear more apt to resort to bullying behaviors than leaders who embrace other-oriented leadership approaches [7].

Given the severity of the workplace bullying problem and the literature finding around rational self-interest leadership, the research for the current article centered on the rational self-interest leader behavior and its effect on employees. Rational self-interest behavior is defined as "thinking and acting in a manner that is expected to lead to an optimal or maximum result for a person on the basis of consideration of the person's values and risk preferences” (p. 946) [8]. Because relationships are seen as transactional in nature and void of emotion, rational selfinterested leaders rely on systematic reasoning to ensure that their personal goals are met. Rational self-interested leaders tend to concern themselves with organizational objectives coupled with a self-emphasis [7]. 
Unlike rational self-interested leaders, other-oriented leaders focus their attention on organizational objectives coupled with a human resource emphasis [7]. Other-oriented leaders rely on the internalization, adherence and enforcement of societal norms rather than systematic reasoning [9]. Other-oriented leaders embrace prosocial behaviors that promote and uphold the value of employees.

\section{The Rational Self-interested Leader and Transactional Leadership}

Transactional leadership is an example of a leadership approach that projects self-interest by nature. Transactional leadership focuses on the exchange between leaders and followers, with both parties receiving something of value [10]. The employees perform tasks and leaders monetarily reward them for their efforts. Transactional leaders as those leaders who do not focus on the individual needs of their followers; rather they look to exchange things of value to advance their own and their followers' agendas [11]. Transactional leaders use positive and negative motivation. Positive motivation focuses on praise, promise and rewards. Negative motivation focuses on negative feedback, threats or disciplinary action [12].

Transactional leaders avoid taking positive action as long as the goals of the organization are being met [13, 14]. They use either contingent awards or management by exception. Contingent awards focus on the exchange of rewards for meeting goals or objectives. Management by exception focuses on negative feedback and corrective action, a punitive approach to management [11]. In other cases of management by exception, leaders take a handsoff approach and avoid leading.

With transactional leadership, the transaction becomes more important than the employees wellbeing. Leaders are not interested in nurturing and preserving relationships with employees; they are interested in ensuring that tasks are completed in order to achieve desired outcomes. This myopic view of the leader-employee relationship sets the foundation for toxic interactions, as preserving the humanness and dignity of employees is not a priority [1].

\section{Workplace Bullying}

Workplace bullying is a chronic stressor, which negatively affects employees and organizations [15]. Bullying is the reliance on repetitive hostile or aggressive behaviors, which offend, humiliate, and harass targeted individuals, thus causing them significant stress [15]. Workplace bullying is repetitive, abusive behavior that devalues and harms people in the work environment [1]. Workplace bullying is not limited to one individual but can include groups, even functioning organizational units [16].

Workplace bullying has a devastating effect on the individual and the organization [17]. It intimidates and torments the targeted individual, putting his or her selfesteem and overall health at risk $[1,18]$. Workplace bullying is an extreme social phenomenon that is triggered by social stressors and social defeats that cause negative bio psychosocial stress reactions and health hazards for the targeted individuals [19]. It is a form of stress at work caused by repeated, systematic exposure to negative acts [20]. Workplace bullying is a significant health and safety issue that occurs between leaders, managers, coworkers and employees. It is prevalent across industries and at all levels within the organizational structure. No one is exempt from experiencing workplace bullying.

Bullies often have a desire to dominate their relationships and are controlling and manipulative [21]. Bullies tend to display little compassion toward targeted individuals and rely on exploitative behavior as a way of dominating the relationships they have with others. When bullying occurs in the workplace, it is difficult for targeted individuals to stop the behavior [22]. Targeted employees are often not aware of the bullying until an extended period of time has passed. They suspect that something is wrong yet may not understand that what they are experiencing is being bullied [1].

\section{Method}

A quantitative method utilizing a correlational design was used in the study to determine the extent to which rational self-interested leaders rely on bullying behaviors when interacting with employees. The participants were 355 American and Canadian employees employed in a variety of industries such as healthcare, manufacturing, financial, retail, public service, and education. Data were collected over an 8-month period using an online survey. The Research Ethics Board at Brock University approved the study. Participation was voluntary. Due to the sensitive nature of the topic, participants' identity remained anonymous. Participants provided consent by completing and submitting the survey.

Participants indicated their gender, age, employment status and length of service. These data were collected to determine to what extent employees may experience bullying behaviors based on their gender and age [23]. Data were also collected to see if a relationship existed between demographics and their length of service and employment status as the literature is devoid of analysis pertaining to the variables as they relate to workplace bullying. Eighty percent of the participants were women. Forty-five percent of the participants were between the ages of 46 and 65 years old. Forty-one percent were be- 
tween the ages of 31 and 45 years old and 14\% were between the ages of 18 and 30 years old. Eighty-six percent were full-time employees and $14 \%$ were part-time employees. Fifty-six percent had a length of service between 1 and 10 years and $44 \%$ had a length of service between 11 and 30 years.

A workplace interaction online survey was created using Freeonlinesurveys.com. The survey consisted of 15 statements (See Table 1) representing common bullying behaviors [24]. Using a 5-point Likert type scale rating from Strongly Disagree (1) to Strongly Agree (5), participants were asked to rate bullying behaviors based on their experiences. The categories for bullying behaviors are:

1) Threat to Professional Status: humiliating the person in public or sabotaging the person's work.

2) Threat to Personal Standing: name calling, spreading malicious rumors about a person, teasing or intimidating a person.

3) Isolation: preventing access to opportunities or isolating the person physically or socially.

4) Overwork: imposing undue pressure to produce work and setting impossible deadlines.

5) Destabilization: failing to give credit where it is due, failure to acknowledge or reward, assigning meaningless tasks, removing responsibility or setting the person up for failure.

Some of the statements refer to co-workers because employees often mimic the behavior that their leaders display. Leaders will subtly encourage employees to interact with targeted individuals in the same manner that they do. The mimicking behavior is known as mobbing, which occurs when individuals experience harassment by leaders and colleagues causing them to be socially excluded at work [25].

Table 1. Fifteen bullying behavior statements.

I have been publicly humiliated and embarrassed by a supervisor or co-worker.

My boss constantly watches me.

I have been ostracized at work.

I have been regularly denied promotions even though I was qualified for the position.

I have been teased at work.

I have been physically assaulted or received threats of assault at work.

My work has been sabotaged.

I am not acknowledged nor rewarded for doing a good job.

I have not received credit for work I have completed.

My boss displays intimidating behavior towards me, such as yelling \& tempers tantrums.

I am regularly assigned meaningless tasks or less desirable tasks.

I am often talked to in a sarcastic manner and often feel "put down".

I am regularly given unreasonable deadlines.

Abusive or degrading language is often used by my boss or co-worker.

I have been the target of malicious rumors.

Source: Workplace Interaction Survey, 2009.

\section{Results}

To answer the research question, "What is the likelihood that American and Canadian employees will experience workplace bullying?" four hypotheses were tested to determine if there is a relationship between having experienced bullying behavior vs. the employee's age group, gender, employment status and length of service. A Chi Square test of independence was performed for each hypothesis. The results of the Chi Square tests indicate a significant relationship exists between employee demographics vs. certain bullying behaviors associated with threats to personal standing, professional status and destabilization.

For the statement "I have been the target of malicious rumors", which is a threat to one's personal standing, Tables 2-4 show the cross tabulation of the Likert type responses vs. employee age, gender and length of service.

Table 2. Rumors vs. age cross tabulations.

\begin{tabular}{lcccc}
\hline & $\mathbf{1 8} \mathbf{- 3 0}$ & $\mathbf{3 1} \mathbf{- 4 5}$ & $\mathbf{4 6} \mathbf{- 6 5}$ & Total \\
\hline Strongly Disagree & 32 & 45 & 56 & 133 \\
Disagree & 11 & 45 & 35 & 91 \\
Undecided & 2 & 17 & 14 & 33 \\
Agree & 1 & 20 & 28 & 49 \\
Strongly Agree & 3 & 17 & 27 & 47 \\
Total & $\mathbf{4 9}$ & $\mathbf{1 4 4}$ & $\mathbf{1 6 0}$ & $\mathbf{3 5 3}$ \\
\hline
\end{tabular}

Note: Pearson Chi Square $=27.216$, Sig. level $=0.001^{* *}$.

Table 3. Rumors vs. gender cross tabulations.

\begin{tabular}{lccc}
\hline & Male & Female & Total \\
\hline Strongly Disagree & 29 & 104 & 133 \\
Disagree & 13 & 78 & 91 \\
Undecided & 12 & 21 & 33 \\
Agree & 6 & 43 & 49 \\
Strongly Agree & 12 & 34 & 46 \\
Total & 72 & 280 & 352 \\
\hline
\end{tabular}

Note: Pearson Chi Square $=10.337$, Sig. level $=0.035^{*}$.

Table 4. Rumors vs. length of service cross-tabulations.

\begin{tabular}{lccccc}
\hline & $\begin{array}{c}\mathbf{0}-\mathbf{1} \\
\text { year }\end{array}$ & $\begin{array}{c}\mathbf{2}-\mathbf{1 0} \\
\text { years }\end{array}$ & $\begin{array}{c}\mathbf{1 1}-\mathbf{2 0} \\
\text { years }\end{array}$ & $\begin{array}{c}\mathbf{2 1 +} \\
\text { years }\end{array}$ & Total \\
\hline Strongly Disagree & 23 & 65 & 25 & 20 & 133 \\
Disagree & 8 & 40 & 27 & 16 & 91 \\
Undecided & 2 & 13 & 13 & 5 & 33 \\
Agree & 2 & 23 & 16 & 8 & 49 \\
Strongly Agree & 3 & 18 & 12 & 14 & 47 \\
Total & 38 & 159 & 93 & 63 & 353 \\
\hline
\end{tabular}

Note: Pearson Chi Square $=21.036$, Sig. level $=0.049^{*}$. 
While about one-third of the oldest group agreed with the statement regarding rumors; one-fourth of the middle group also agreed, and less than one-tenth of the youngest group agreed. The results imply that the longer one is in the workplace, the more likely he/she will experience being the target of malicious rumors.

Whereas a similar percentage of men and women agreed that they experienced rumors, a significantly larger group of women disagreed while more men were undecided as to whether they experienced malicious rumors (See Table 3). It can be concluded that experiencing malicious rumors is gender-neutral; while men are more likely to be uncertain or noncommittal as to whether it is true.

As with age, the employees with a longer length of service were more inclined to have been the targets of malicious rumors (See Table 4). There was no indication when the experience may have occurred during one's employment. Given time, an employee's chances of being the target of rumors grows, as evidenced by $13 \%$ of the newer employee group agreeing, vs. $26 \%$ of the 2 10 years group, vs. $30 \%$ of the $11-20$ years group vs. $35 \%$ of the $21+$ years group.

For the statement "I have been publicly humiliated and embarrassed by a supervisor or coworkers," which is a threat to one's professional status, Tables 5-6 show the cross tabulation of the Likert-type responses vs. employee status and length of service.

Table 5. Public humiliation vs. employment status cross tabulations.

\begin{tabular}{lccc}
\hline & Full-time & Part-time & Total \\
\hline Strongly Disagree & 59 & 10 & 69 \\
Disagree & 77 & 17 & 94 \\
Undecided & 16 & 0 & 16 \\
Agree & 83 & 3 & 86 \\
Strongly Agree & 66 & 7 & 73 \\
Total & 301 & 37 & 338 \\
\hline
\end{tabular}

Note: Pearson Chi Square $=12.816$, Sig. level $=0.012^{*}$.

Table 6. Public humiliation vs. length of service cross tabulations.

\begin{tabular}{lccccc}
\hline & $\begin{array}{c}\mathbf{0 ~ - ~ 1 ~} \\
\text { year }\end{array}$ & $\begin{array}{c}\mathbf{2 - 1 0} \\
\text { years }\end{array}$ & $\begin{array}{c}\mathbf{1 1 ~ - ~ 2 0} \\
\text { years }\end{array}$ & $\begin{array}{c}\mathbf{2 1 +} \\
\text { years }\end{array}$ & Total \\
\hline Strongly Disagree & 14 & 36 & 11 & 11 & 72 \\
Disagree & 10 & 39 & 28 & 19 & 96 \\
Undecided & 5 & 8 & 4 & 2 & 19 \\
Agree & 5 & 44 & 26 & 14 & 89 \\
Strongly Agree & 5 & 32 & 24 & 18 & 79 \\
Total & 39 & 159 & 93 & 64 & 355 \\
\hline
\end{tabular}

Note: Pearson Chi Square $=21.209$, Sig. level $=0.047^{*}$.
While about half of the full-time employees agreed with the statement regarding humiliation, only about onefourth of the part-time employees also agreed. The implication is that the more time one spends in the workplace, the more likely he/she will experience public humiliation from supervisors or co-workers. The finding could also be attributed to the fact that a part-time employee is not likely to remain with the company as long as a full-time employee.

Similar to the statement about rumors, the employees with a longer length of service were more inclined to have been the targets of public humiliation at the hands of their bosses and co-workers (See Table 6). The finding makes sense since more time on the job presents greater opportunities for such bullying. While about onefourth of the newer employee group had a public humiliation experience, half of the $21+$ years group also did.

For the statement "I am not acknowledged nor rewarded for doing a good job," which is a destabilization behavior, Table 7 shows the cross tabulation of the Likert type responses vs. employee status.

The test results revealed that full-time employees were more likely than part-time employees to feel they were not acknowledged or rewarded for their job performance. When employees are not acknowledged or rewarded, employees become demotivated and may not want to contribute to the organizational efforts. Subsequently, employees may begin to disengage from the organization, resulting in a decrease in organizational commitment and an increase in efforts to exit the company [22,26]. Parttime employees are not typically eligible for rewards, and so may be less inclined to feel troubled by not being acknowledged or rewarded for their efforts.

\section{Discussion}

Evidence from the results of the study support the premise that American and Canadian employees who interact with rational self-interested leaders will likely experience behaviors that are associated with workplace bullying. In the rational self-interested leaders' efforts to achieve de-

Table 7. Acknowledgement/reward vs. employment status cross tabulations.

\begin{tabular}{lccc}
\hline & Full-time & Part-time & Total \\
\hline Strongly Disagree & 66 & 11 & 77 \\
Disagree & 79 & 14 & 93 \\
Undecided & 42 & 3 & 45 \\
Agree & 76 & 2 & 78 \\
Strongly Agree & 35 & 7 & 42 \\
Total & 298 & 37 & 335 \\
\hline
\end{tabular}

Note: Pearson Chi Square $=10.283$, Sig. level $=0.036^{*}$. 
sired organizational and personal outcomes and to uphold their personal value, they may seek to devalue employees by threatening their professional status and personal standing. The rational self-interested leaders may rely on public humiliation and rumors to ensure that targeted employees are not identified as valuable contributors to the organization. Rational self-interested leaders may further seek to devalue employees by not acknowledging and rewarding them for their positive work performance, which confirms the leaders' belief that the targeted employees are of little value to the organization and are not worthy of receiving positive reinforcement. By adopting bullying behaviors, the rational self-interested leaders are personally contributing to the creation of a hostile work environment, which will inevitably negatively affect both the targeted employees and the organization's overall effectiveness. Employees most likely to experience bullying are full-time, employees who have been with the organization for a long period of time as evidenced by the findings of the study. More likely than not long term employees' professional status and personal standing will be threatened as rational self-interested leaders seek to harm and devalue them. Regardless of the employees' positive job performance, their efforts may not be acknowledged or rewarded. Employees who are neither acknowledged nor rewarded for their efforts may begin to adopt negative attitudes about themselves and the organization. The negativity experienced by the targeted employees could affect their ability to positively contribute to the organization putting the employees at risk of disciplinary action and possible job loss. The negative outcomes could be in alignment with the rational selfinterested leaders' agenda and could have a devastating effect on targeted employees and further reduce organizational productivity. Finally, the negative interactions observed by part-time employees may cause them not to seek full-time employment status for fear of becoming targets of workplace bullying. The part-time employees may further decide not to contribute to the organization at their fullest potential because their efforts are likely to go unnoticed and unrewarded. Workplace bullying has a domino negative effect on full-time employees, part-time employees as well as organizations. Organizations may lose valuable and talented employees as a result of bullying behaviors that exist. Not only will organizations lose talented employees, they will carry the financial burden of replacing such individuals. Employees, who leave the workplace due to negative interactions, either involuntarily or voluntarily, cost American companies billions of dollars per year. Stress, loss in productivity and replacement of employees are contributing factors to the indirect and direct costs incurred by organizations.

\section{Conclusion}

Rational self-interested leaders contribute to the workplace bullying phenomenon by relying on behaviors that threaten the employees' personal standing, professional status and are destabilizing. The workplace bullying phenomenon will continue to increase if rational self-interested leaders continue to embrace attitudes and behaviors that devalue employees and do not uphold their humanness. Rational self-interested leaders seeking to lead successfully in the $21^{\text {st }}$ century will need to restrain their bullying behaviors and embrace behaviors that are prosocial and other-oriented. Bullying behaviors are learned behaviors indicating that rational self-interested leaders may need to learn how to incorporate more positive behaviors in their interactions with employees. In choosing positive choices of action, rational self-interested leaders will need to explore their pre-existing knowledge of workplace bullying and engage in meaningful learning that occurs at the conceptual level [27]. Addressing workplace bullying in a proactive manner will set the foundation for rational self-interested leaders to adopt behaviors that are prosocial and other-oriented. Embracing prosocial and other-oriented behaviors will contribute to the eradication of bullying in the workplace and will promote a safe and healthy work environment for all employees.

\section{REFERENCES}

[1] L. M. S. Barrow, "In Darkness Light Dawns: Exposing Workplace Bullying,” Purple Crown Publishing, Port Colborne, 2009

[2] N. Djurkovic, D. McCormack, and G. Casimir, "The Behavioral Reactions of Victims to Different Types of Workplace Bullying," International Journal of Organization Theory and Behavior, Vol. 8, No. 4, 2005, pp. 439460.

[3] G. Namie and R. Namie, “The Bully at Work,” 2nd Edition, Sourcebooks, Naperville, 2009.

[4] F. Bulutlar and E. U. Öz, "The Effects of Ethical Climates on Bullying Behaviour in the Workplace," Journal of Business Ethics, Vol. 86, No. 3, 2009, pp. 273-295. http://dx.doi.org/10.1007/s10551-008-9847-4

[5] O. B. Ayoko, V. J. Callan and C. J. Härtel, "Workplace, Conflict, Bullying, and Counterproductive Behavior,” International Journal of Organizational Analysis, Vol. 11, No. 4, 2003, pp. 283-301.

[6] Workplace Bullying Institute \& Zogby International, 2007.

http://www.workplacebullying.org/research/WBI-Zogby2 007Survey.html

[7] L. M. S. Barrow and J. Mirabella, “An Empirical Study of Other-Oriented and Rational Self-Interested Leadership Approaches,” Journal of Leadership Studies, Vol. 3, No. 


\section{2, 2009, pp. 44-54. http://dx.doi.org/10.1002/jls.20107}

[8] B. M. Meglino and M. A. Korsgaard, "Considering the Rational Self-Interest as a Disposition: Organizational Implications of Other Orientation," Journal of Applied Psychology, Vol. 89, No. 6, 2004, pp. 946-959.

http://dx.doi.org/10.1037/0021-9010.89.6.946

[9] B. M. Meglino and M. A. Korsgaard, “The Role of Other Orientation in Reactions to Job Characteristics," Journal of Management, Vol. 33, No. 1, 2007, pp. 57-83. http://dx.doi.org/10.1177/0149206306295308

[10] S. Boerner, S. Eisenbeiss and D. Griesser, "Follower Behavior and Organizational Performance: The Impact of Transformational Leaders," Journal of Leadership and Organizational Studies, Vol. 13, No. 3, 2007, pp. 15-27. http://dx.doi.org/10.1177/10717919070130030201

[11] P. Northouse, "Leadership: Theory and Practice," Thousand Oaks, CA: Sage Publications, 2007

[12] B. Bass and D. Steidlmeier, "Ethics, Character and Authentic Transformational Leadership Behavior,” Leadership Quarterly, Vol. 10, No. 2, 1999, pp. 181-217. http://dx.doi.org/10.1016/S1048-9843(99)00016-8

[13] J. Humphreys, "Transformational and Transactional Leader Behavior,” Journal of Management Research, Vol. 1, No. 3, 2001, pp. 149-159.

[14] K. Kuhnert and P. Lewis, "Transactional and Transformational Leadership: A Constructive/Development Analysis,” Academy of Management Review, Vol. 12, No. 4, 1987, pp. 648-657.

[15] S. Einarsen, "The Nature and Causes of Bullying at Work," International Journal of Manpower, Vol. 20, No. 1/2, 1999, pp.16-20. http://dx.doi.org/10.1108/01437729910268588

[16] M. Hutchinson, M. Vickers D. Jackson and L. Wilkes, "Like Wolves in a Pack: Predatory Alliances of Bullies in Nursing," Journal of Management and Organization, Vol. 12, No. 3, 2006, pp. 235-251. http://dx.doi.org/10.5172/jmo.2006.12.3.235

[17] M. Vickers, "Bullying as Unacknowledged Organizational Evil: A Researcher's Story,” Employee Responsibilities and Rights Journal, Vol. 13, No. 4, 2002, pp. 207-217.

[18] V. Braithwaite, E. Ahmed and J. Braithwaite, "Workplace Bullying and Victimization: The Influence of Organizational Context, Shame and Pride,” International Journal of Organisational Behaviour, Vol. 13, No. 2,
2008, pp. 71-94.

[19] M. K. Strandmark and L. R. Hallberg, "The Origin of Workplace Bullying: Experiences from the Perspective of Bully Victims in the Public Service Sector," Journal of Nursing Management, Vol. 15, No. 3, 2007, pp. 332-341. http://dx.doi.org/10.1111/j.1365-2834.2007.00662.x

[20] S. A. Bond, M. R. Tuckey and M. F. Dollard, "Psychosocial Safety Climate, Workplace Bullying, and Symptoms of Post Traumatic Stress,” Organization Development Journal, Vol. 28, No. 1, 2010, p. 37.

[21] M. Cleary, G. E. Hunt, G. Walter and M. Robertson, "Dealing with Bullying in the Workplace: Toward Zero Tolerance," Journal of Psychosocial Nursing \& Mental Health Services, Vol. 47, No. 12, 2009, pp. 34-41. http://dx.doi.org/10.3928/02793695-20091103-03

[22] P. D’Cruz and E. Noronha, “The Exit Coping Response to Workplace Bullying,” Employee Relations, Vol. 32, No. 2, 2010, pp. 102-120. http://dx.doi.org/10.1108/01425451011010078

[23] A. Ortega, A. Høgh, J. Pejtersen, J. Hyld and O. Olsen, "Prevalence of Workplace Bullying and Risk Groups: A Representative Population Study,” International Archives of Occupational and Environmental Health, Vol. 82, No. 3, 2009, pp. 417-426. http://dx.doi.org/10.1007/s00420-008-0339-8

[24] C. Rayner and H. Hoel, "A Summary Review of Literature Relating to Workplace Bullying," Journal of Community \& Applied Social Psychology, Vol. 7, No. 3, 1997, pp. 181-191.

http://dx.doi.org/10.1002/(SICI)1099-1298(199706)7:3<1 81::AID-CASP416>3.0.CO;2-Y

[25] L. Sperry, "Mobbing and Bullying: The Influence of Individual, Work Group, Andorganizational Dynamics on Abusive Workplace Behavior,” Consulting Psychology Journal Practice and Research, Vol. 61, No. 3, 2009, pp. 190-201. http://dx.doi.org/10.1037/a0016938

[26] D. Zapf and C. Gross, "Conflict Escalation and Coping with Workplace Bullying: A Replication and Extension," European Journal of Work and Organizational Psychology, Vol. 10, No. 4, 2001, pp. 497-522. http://dx.doi.org/10.1080/13594320143000834

[27] B. A. Altman, "Workplace Bullying: Application of Novak's (1998) Learning Theory and Implications for Training," Employee Responsibilities and Rights Journal, Vol. 22, No. 1, 2010, pp. 21-32. http://dx.doi.org/10.1007/s10672-009-9121-7 